Zeszyty Naukowe Szkoły Głównej Gospodarstwa Wiejskiego

Ekonomika i Organizacja Gospodarki Żywnościowej nr 111, 2015: 61-70

Lilianna Jabłońska, Lidia Gunerka, Krystian Leasing

Samodzielna Pracownia Organizacji i Ekonomiki Ogrodnictwa

Szkoła Główna Gospodarstwa Wiejskiego w Warszawie

\title{
Postęp w uprawie róż szklarniowych i jego efekty produkcyjno-ekonomiczne na przykładzie wybranego gospodarstwa
}

\section{Wstęp}

W warunkach rosnącej globalizacji rozwój gospodarki ogrodniczej uzależniony jest od jej zdolności do konkurowania, a ta zależy m.in. od poziomu kosztów oraz zróżnicowania produktów pod względem szeroko rozumianej jakości zgodnej z wymaganiami konsumenta [Nosecka, Pawlak i Poczta 2011]. Kluczem do zwiększania efektywności produkcji, uzyskania i utrzymania przewagi konkurencyjnej i rozwoju sektora, a tym samym pozostania w nim producentów jest postęp [Jabłońska 1995, Majewski 1997, Frankowska 2011]. Dotyczy to także produkcji kwiatów pod osłonami, rozwojowi której w Polsce [Jabłońska i Olewnicki 2011] towarzyszy od lat 90. wzrost ich importu [Jabłońska i Olewnicki 2013]. Tak w produkcji, jak i w imporcie istotną rolę odgrywają róże, stąd stopniowo zwiększa się ich konkurencja na rynku wewnętrznym. Równocześnie ceny kwiatów rosną wolniej niż czynników produkcji [Wróblewska i Gunerka 2014]. W tych warunkach producenci, chcąc utrzymać się na rynku, muszą obniżać jednostkowe koszty produkcji i zwiększać przychody z $1 \mathrm{~m}^{2} \mathrm{~m}$.in. przez podnoszenie plonów, wdrażanie najnowszych technik i technologii uprawy i działań posprzętnych. Celem pracy jest przedstawienie nowoczesnych rozwiązań $\mathrm{w}$ uprawie róż szklarniowych wdrażanych przez polskich producentów na przykładzie wybranego gospodarstwa oraz ocena efektów ekonomicznych tego postępu. 


\section{Metodyka}

Praca składa się z dwóch części. W pierwszej dokonano opisu badanego gospodarstwa pod kątem zmian wprowadzanych w uprawie róż szklarniowych. Przedstawiono kolejno nowoczesne rozwiązania techniczne i technologiczne mające zastosowanie w budownictwie szklarniowym i w samej uprawie, które wdrożono w gospodarstwie, wskazując jednocześnie (na podstawie literatury) korzyści, jakie przynosi każde z nich. W drugiej przeprowadzono analizę kosztów i wyników produkcyjno-ekonomicznych oraz opłacalności produkcji dla całego gospodarstwa, a także dla każdej z dwóch szklarni różniących się poziomem stosowanych technik i technologii. Badania obejmują lata 2008-2009.

W badanym gospodarstwie prowadzone są tylko niesystematyczne notatki dotyczące zakupów i zużycia środków produkcji, usług i pracy najemnej oraz gromadzone rachunki i faktury. Pozwoliły one jednak, wraz z informacjami uzyskanymi od właściciela, na oszacowanie kosztów bezpośrednich i pośrednich rzeczywistych. W rachunku kosztów nie uwzględniono amortyzacji budynków i pracy własnej, uwzględniono zaś, mający wpływ na opłacalność produkcji, podatek od działów specjalnych. Dane uzyskane od właściciela odnosiły się do całego gospodarstwa, czyli do starego i nowego obiektu szklarniowego łącznie, stąd, w zależności od rodzaju kosztu, jego wysokość podzielono proporcjonalnie do metro-tygodni uprawy w każdym obiekcie, powierzchni uprawy lub wysokości zbiorów. Tak wyznaczone koszty były podstawą do oszacowania nadwyżki bezpośredniej i dochodu rolniczego brutto, a następnie wskaźnika opłacalności na poziomie tegoż dochodu (wraz z podatkiem), zarówno dla całego gospodarstwa, jak i dwóch typów uprawy róż.

\section{Wyniki badań}

\section{Postęp techniczny i technologiczny w gospodarstwie}

Badane gospodarstwo zajmuje się produkcją kwiatów w szklarniach od 1982 roku. W 1990 roku na całym areale wynoszacym $3500 \mathrm{~m}^{2}$ wprowadzono do produkcji róże uprawiane metodą tradycyjną tzn. w podłożu glebowym, ze spoczynkiem zimowym. W 1993 roku powiększono gospodarstwo o nowoczesny, wielonawowy obiekt szklarniowy typu Venlo o powierzchni $6500 \mathrm{~m}^{2}$. Dzięki zminimalizowaniu powierzchni ścian bocznych oraz pokryciu ich podwójnym szkłem, pozwala on na ograniczenie strat ciepła. Stąd jego jednostkowe zużycie jest w nich o $21 \%$ niższe niż w szklarniach z poprzednich dekad [Rutkowski 2008]. W celu oszczędnego gospodarowania ciepłem zastosowano także nowo- 
czesny system rozmieszczenia rur grzewczych, tzn. nie wyłącznie wzdłuż ścian bocznych, ale także pod i między zagonami, co pozwala utrzymać optymalną temperaturę podłoża i zapewnia dobry rozwój systemu korzeniowego, umożliwiając prawidłowe pobieranie wody i nawozów, a w efekcie uzyskanie wysokich i dobrej jakości plonów.

Wielonawowe, wysokie szklarnie stwarzają również lepsze warunki uprawy roślin, tzn. lepsze ich doświetlenie i łatwiejszą kontrolę klimatu, co nie jest bez znaczenia dla wielkości plonu i jakości kwiatów, a także poprawiają warunki logistyczne i komfort pracy zatrudnionych osób [Rutkowski 2011]. Ponadto ułatwiają uprawę róż na podwyższeniach i stosowanie japońskiej metody prowadzenia krzewów (z przyginaniem pędów do dołu). Jest ona wprowadzona w całym badanym gospodarstwie. Przy tej metodzie rośliny lepiej są nawadniane i nawożone oraz mają lepsze warunki termiczne i oświetlenie, co skutkuje wyższymi plonami [Treder 2000, Rutkowski 2008]. Sadząc róże na zagonach wzniesionych, można zebrać o 10\% większy plon niż w uprawie płaskiej. Łatwiejsze jest także prowadzenie zabiegów pielęgnacyjnych.

Róże w gospodarstwie uprawiane są w podłożu inertnym, którym jest mieszanka torfu, włókna kokosowego, keramzytu i kredy. Takie podłoże, dzięki stworzeniu doskonałych warunków do rozwoju systemu korzeniowego, pozwala na poprawę zdrowotności roślin, uzyskiwanie wyższych i wyrównanych plonów, cięższych i sztywniejszych kwiatów o lepszej jakości [Kleiber i Kleiber 2006]. Ponadto w zastosowanym włóknie kokosowym korzenie róż rozwijają się szybciej i w pierwszym roku uzyskuje się wcześniejszy i większy plon niż w wełnie mineralnej [Treder 2000]. Użycie włókna kokosowego czyni także podłoże mniej podatne na osiadanie, co pozwala wykorzystywać je nawet przez 5-7 lat, obniżając koszty roczne założenia plantacji. Jest też łatwe w utylizacji.

Uprawa róż w podłożach inertnych o małej objętości wymaga bardzo precyzyjnego nawadniania i nawożenia [Treder i Treder 2004], co zapewnia automatyczny system fertygacji sterowany komputerowo. Taki system wprowadzono także w badanym gospodarstwie, z zastosowaniem linii kroplujących połączonych z komputerem nawodnieniowym. Dawki nawozów do pożywki korygowano na podstawie co 3-miesięcznych analiz laboratoryjnych. Jak podkreśla Łukowicz [1993], precyzyjny system fertygacji z automatycznym sterowaniem pozwala zmniejszyć zużycie wody i nawozów nawet o $50 \%$, obniżyć nakłady pracy na nawadnianie i nawożenie o około $80 \%$, podnieść wielkość i jakość plonów. Należy dodać, że woda w gospodarstwie pochodziła z własnej studni głębinowej.

Przy wysokich kosztach inwestycji ponoszonych na wybudowanie nowoczesnej szklarni z wyposażeniem do produkcji róż (ok. $3 \mathrm{mln}$ zł/1 ha), konieczne staje się maksymalne jej wykorzystanie w ciągu roku. Zaczęto więc odchodzić 
od tradycyjnej uprawy róż ze spoczynkiem zimowym, a przechodzić na uprawę całoroczną. By jednak uzyskać kwitnące pędy, zimą niezbędne jest doświetlanie. W ten sposób można zwiększyć plon róż od 20 do $110 \%$ w zależności od odmiany [Drzewiecka 2009]. W badanym gospodarstwie doświetlanie stosowano tylko w nowych szklarniach, gdyż stary obiekt nie gwarantował utrzymania na optymalnym poziomie parametrów klimatu koniecznych do osiągnięcia efektów doświetlania. Tu róże wprowadzano w stan spoczynku.

W obiektach zamkniętych jakimi są szklarnie występują niedobory niezbędnego do życia roślin $\mathrm{CO}_{2}$, największe $\mathrm{w}$ nowoczesnych, dobrze uszczelnionych obiektach i zimą, gdy ograniczone jest wietrzenie. Stąd w uprawie całorocznej róż z doświetlaniem należy stosować dokarmianie roślin $\mathrm{CO}_{2}$, które przyczynia się do: zwiększenia świeżej masy roślin nawet o 50\%, zmniejszenia liczby pędów płonnych, przyspieszenia kwitnienia, ograniczenia zamierania pędów kwiatowych, zwiększenia plonu kwiatów, ich jakości i trwałości [Nowak 1993]. $\mathrm{W}$ badanym gospodarstwie również dokarmiano róże $\mathrm{CO}_{2}$, utrzymując jego poziom w okresie doświetlania na optymalnym poziomie przy wykorzystaniu komputera klimatycznego.

Badane gospodarstwo wdrożyło również nowoczesne rozwiązania w ochronie roślin, tzn. ochronę integrowaną, kładącą nacisk na walkę biologiczną za szkodnikami. Prowadzona była ona przez firmę zewnętrzną, która co tydzień prowadziła lustrację roślin i tam gdzie wystapiła konieczność, rozprowadzała preparaty biologiczne $z$ entomofagiem oraz oznaczała miejsca wymagające dodatkowo oprysku środkiem chemicznym. Ten ostatni wykonywany był przez producenta we własnym zakresie. Taka organizacja zabiegów ochrony daje gwarancję efektywnego ich wykonania.

Istotną sprawą w produkcji róż jest zbiór kwiatów, ich traktowanie pozbiorcze i przygotowanie do sprzedaży. W gospodarstwie zbiór, sortowanie i pakowanie wykonywane były ręcznie, gdyż przy istniejącej skali produkcji nieopłacalny był zakup automatycznej linii do sortowania i pakowania. Ponadto, zdaniem właściciela, ręczne sortowanie i układanie pozwala uzyskać wysoką jakość opakowania handlowego. Opakowane kwiaty trafiały do chłodni wybudowanej wraz ze szklarnią, gdzie przechowywano je w specjalnej pożywce (kondycjonowane) przez 24 godziny. Dopiero po tym okresie były sprzedawane.

\section{Koszty bezpośrednie produkcji}

Koszty bezpośrednie materiałowe to przede wszystkim: koszt opału (miał węglowy) wraz $\mathrm{z}$ transportem, energii elektrycznej, chemicznych środków ochrony roślin, nawozów, $\mathrm{CO}_{2}$ i dzierżawy zbiornika, oleju napędowego, środków do kondycjonowania róż, cylindrów foliowych, folii do pakowania, sznurka 
i taśmy przylepnej, sekatorów, rękawiczek, usług integrowanej ochrony. Należy do nich także koszt założenia plantacji rozłożony na 5-letni cykl uprawy. Łącznie wyniosły one w badanym gospodarstwie $95,96 \mathrm{zl}$ na $1 \mathrm{~m}^{2}$ powierzchni brutto. $\mathrm{W}$ ich strukturze, największy udział, aż $45,7 \%$, stanowiły koszty opału wraz $\mathrm{z}$ transportem, a następnie energii elektrycznej $-28,1 \%$. Na trzecim miejscu, ale na wyraźnie niższym poziomie, był koszt założenia plantacji (11,6\%). Mniejsze znaczenie miały koszty ochrony roślin $(4,0 \%)$, nawożenia i oleju napędowego (po $2,5 \%)$ oraz dokarmiania $\mathrm{CO}_{2}(2,1 \%)$. W pozostałych kosztach, stanowiących $3,2 \%$, dominowały koszty związane z przygotowaniem róż do sprzedaży. Powyższa analiza pokazuje, jak ogromną rolę w produkcji róż szklarniowych w polskich warunkach klimatycznych mają koszty ogrzewania, rosnące wraz z wydłużaniem uprawy na miesiące zimowe, a także koszty doświetlania. W badanym gospodarstwie stanowiły one łącznie $73,8 \%$ kosztów materiałowych. Stąd też prowadzenie uprawy w cyklu rocznym, choć pozwalają na to rozwiązania techniczne i technologiczne, bardzo uzależnione jest od cen energii cieplnej i energii elektrycznej.

W łącznych kosztach bezpośrednich udział kosztów ogrzewania wynosił $30,6 \%$, a energii elektrycznej $18,8 \%$. Dla porównania w latach 90 . w uprawie tradycyjnej było to odpowiednio około 49 i 1\% [Kubiak i Marynowski 1997]. Zmianie uległ także udział kosztów pracy najemnej - w badanym gospodarstwie stanowiły one $33,1 \%$ kosztów bezpośrednich, przy $17,8 \% \mathrm{w}$ uprawie tradycyjnej. W warunkach automatyzacji wielu prac był to głównie efekt znacznie wyższych plonów. Gros nakładów pracy związana była ze zbiorem, traktowaniem posprzętnym i przygotowaniem róż do sprzedaży. Na silną korelację między zbiorami a nakładami pracy wskazuje współczynnik Pearsona wynoszący 0,81 . Zdaniem właściciela, najbardziej pracochłonne zajęcia to sortowanie, czyszczenie $\mathrm{z}$ dolnych liści, układanie i pakowanie $\mathrm{w}$ paczki. $\mathrm{W}$ badanym gospodarstwie przy średnim plonie $148 \mathrm{szt} / \mathrm{m}^{2}$ nakład pracy wynosił $5,6 \mathrm{rbg} / \mathrm{m}^{2}$, natomiast w uprawie tradycyjnej plon róż wynosił jedynie $72 \mathrm{szt} / \mathrm{m}^{2}$, a nakłady pracy $2,2 \mathrm{rbg} / \mathrm{m}^{2}$, w tym przeznaczone na zbiór stanowiły tylko $23 \%$ (lata 90 .).

\section{Koszty pośrednie rzeczywiste}

Do kosztów pośrednich rzeczywistych wliczono cały szereg kosztów związanych z prowadzeniem gospodarstwa, m.in. remonty budynków i maszyn wraz ze szkłem i częściami zamiennymi, analizy wody i podłoża, transport zewnętrzny, telefon i internet, wywóz śmieci, odprowadzenie ścieków, KRUS, ubezpieczenie budynków i samochodów, odsetki od kredytów i prowizje bankowe, podatek rolny, a także podatek dochodowy od działów specjalnych. Część z tych kosztów dotyczyła całego gospodarstwa, włącznie z gospodarstwem domowym 
i niemożliwe było wyodrębnienie z nich części obciążającej jedynie produkcję. Tu oparto się na wiedzy i doświadczeniu właściciela, zdaniem którego produkcję róż obciąża około $75 \%$ wszystkich powyższych kosztów. Tak więc wysokość kosztów pośrednich rzeczywistych w przeliczeniu na $1 \mathrm{~m}^{2} \mathrm{w}$ badanym gospodarstwie wyniosła 12,75 zł. Największy udział stanowiły w nich koszty remontów i napraw $(24,5 \%)$, następnie KRUS $(11,5 \%)$, odsetki od kredytu $(8,9 \%)$ i prowizje bankowe $(9,1 \%)$, ubezpieczenie samochodów $(7,5 \%)$ i podatek dochodowy $(5,0 \%)$. W latach 90 . obciążenie $1 \mathrm{~m}^{2}$ kosztami pośrednimi było na poziomie 12,4 zł, w tym składka KRUS i podatek dochodowy stanowiły 20,1 i 9,8\% [Kubiak i Marynowski 1997].

\section{Wielkość produkcji}

W badanym gospodarstwie, jak już zaznaczono, wielkość produkcji z $1 \mathrm{~m}^{2}$ wynosiła 148,3 sztuk róż, przy czym znacznie wyższa była w przypadku uprawy całorocznej prowadzonej w nowej szklarni. Tu z $1 \mathrm{~m}^{2}$ uzyskano średnio 168,9 sztuk, podczas gdy w starym obiekcie w uprawie z zimowym spoczynkiem 110,1 sztuk (tab. 1). Generalnie, gospodarstwo osiagało relatywnie wysokie plony, gdyż

\section{Tabela 1}

Wyniki produkcyjno-ekonomiczne w uprawie róż szklarniowych w badanym gospodarstwie w 2008 roku

\begin{tabular}{|c|c|c|c|c|c|c|}
\hline \multirow[b]{3}{*}{ Wyszczególnienie } & \multicolumn{3}{|c|}{$\mathrm{z} ł / \mathrm{m}^{2}$} & \multicolumn{3}{|c|}{$\mathrm{z}$ /szt } \\
\hline & \multirow[b]{2}{*}{$\begin{array}{l}\text { gospo- } \\
\text { darstwo } \\
\text { ogółem }\end{array}$} & \multicolumn{2}{|c|}{ uprawa } & \multirow[b]{2}{*}{$\begin{array}{l}\text { gospo- } \\
\text { darstwo } \\
\text { ogółem }\end{array}$} & \multicolumn{2}{|c|}{ uprawa } \\
\hline & & $\begin{array}{l}\text { spoczy- } \\
\text { nek } \\
\text { zimowy }\end{array}$ & $\begin{array}{l}\text { całoro- } \\
\text { czna }\end{array}$ & & $\begin{array}{l}\text { spoczy- } \\
\text { nek zi- } \\
\text { mowy }\end{array}$ & $\begin{array}{l}\text { całoro- } \\
\text { czna }\end{array}$ \\
\hline Średni plon szt/m² & 148,31 & 110,10 & 168,90 & - & - & - \\
\hline Wartość produkcji & 188,35 & 126,61 & 219,54 & 1,27 & 1,15 & 1,30 \\
\hline $\begin{array}{l}\text { Koszty bezpośrednie, } \\
\text { w tym: }\end{array}$ & 143,17 & 94,68 & 169,40 & 0,97 & 0,86 & 1,00 \\
\hline materiałowe & 95,96 & 59,45 & 115,64 & 0,65 & 0,54 & 0,68 \\
\hline siły roboczej najemnej & 47,21 & 35,23 & 53,76 & 0,32 & 0,32 & 0,32 \\
\hline $\begin{array}{l}\text { Koszty pośrednie rzeczy- } \\
\text { wiste + podatek od działów } \\
\text { specjalnych }\end{array}$ & 12,75 & 12,75 & 12,75 & 0,09 & 0,12 & 0,08 \\
\hline Suma kosztów & 155,92 & 107,43 & 182,15 & 1,06 & 0,98 & 1,08 \\
\hline \multicolumn{7}{|c|}{ Wyniki finansowe } \\
\hline Nadwyżka bezpośrednia & 45,18 & 31,93 & 50,14 & 0,30 & 0,29 & 0,30 \\
\hline Dochód rolniczy brutto & 32,43 & 19,18 & 37,39 & 0,21 & 0,18 & 0,22 \\
\hline \multicolumn{7}{|c|}{ Wskaźnik efektywności ekonomicznej } \\
\hline Wskaźnik opłacalności $^{*}$ & 120,8 & 117,8 & 120,5 & 119,8 & 117,3 & 120,3 \\
\hline
\end{tabular}

*na poziomie dochodu rolniczego.

Źródło: Badania własne. 
w uprawach tradycyjnych z przerwą zimową średnio w Polsce wynosiły 70-100 sztuk [Jabłońska 1995, Kubiak i Marynowski 1997], a plony odmian uprawianych $\mathrm{w}$ gospodarstwie w cyklu rocznym były na poziomie $90-92 \%$ plonów katalogowych.

Dzięki doświetlaniu większość róż w gospodarstwie kwitła przez cały rok i zbiory odbywały się w każdym miesiącu. Najmniejsze były w listopadzie, grudniu, styczniu i lutym, kiedy róże w starym obiekcie wprowadzano w stan spoczynku. Największe zaś w czerwcu, lipcu i sierpniu, czyli w miesiącach o najsilniejszym kwitnieniu wynikającym z korzystnych warunków fotosyntezy (długi dzień i duże natężenie światła). Odmienny przebieg miały ceny róż, czyli niskie były w miesiącach letnich, wysokie zaś w zimowych. Najwyższe ceny osiagały róże w lutym i marcu, głównie za sprawą popularnych Walentynek i Dnia Kobiet. Stanowiły wówczas $140 \%$ średniej ceny rocznej, podczas gdy w sierpniu $70 \%$. Wyłączenia części plantacji z kwitnienia w okresie najwyższych cen nie uważano jednak w gospodarstwie za minus, gdyż są to miesiące o relatywnie niskim popycie na kwiaty i nasiliłyby się problemy z ich zbytem. Przy tej skali produkcji nie brano pod uwagę eksportu róż.

\section{Wyniki finansowe i ekonomiczna efektywność produkcji}

Wartość całej towarowej produkcji w badanym gospodarstwie wyniosła średnio $188,35 \mathrm{z} / \mathrm{m}^{2}$, ale $\mathrm{w}$ uprawie całorocznej z doświetlaniem było to $219,54 \mathrm{z} ł / \mathrm{m}^{2}$ przy $126,61 \mathrm{zz} / \mathrm{m}^{2} \mathrm{w}$ uprawie bez doświetlania. Również znacznie wyższe były w uprawie całorocznej koszty materiałowe i siły roboczej, które łącznie z kosztami pośrednimi rzeczywistymi wynosiły $182,15 \mathrm{zz} / \mathrm{m}^{2}$. W uprawie 9 -miesięcznej kształtowały się na poziomie $107,43 \mathrm{zt} / \mathrm{m}^{2}$. W efekcie w uprawie całorocznej uzyskiwano z jednostki powierzchni wyraźnie wyższą nadwyżkę bezpośrednią i wyższy dochód rolniczy brutto niż w uprawie $\mathrm{z}$ usypianiem róż - odpowiednio o 35 i 57\%. W przeliczeniu na sztuki kwiatów różnica była mniejsza - w produkcji całorocznej uzyskiwano dochód rolniczy brutto o $22 \%$ wyższy, ale już nadwyżka bezpośrednia była jedynie o 3\% wyższa. Jest to wynik relatywnie wysokiego obciążenia róż produkowanych w starym obiekcie kosztami pośrednimi rzeczywistymi. Koszty bezpośrednie produkcji 1 róży są wyższe w uprawie całorocznej o $16 \%$, natomiast koszty łączne o $10 \%$.

$\mathrm{Z}$ powyższych analiz wynika, iż uprawa róż jest produkcją dochodowa, a lepsze wyniki finansowe uzyskuje się, wdrażając postęp techniczny i technologiczny. Wskaźnik opłacalności $\mathrm{w}$ szklarni z nowoczesnym systemem uprawy z doświetlaniem wynosił 120,5\%, podczas gdy w szklarni bez doświetlania i ze spoczynkiem zimowym $117,8 \%$. Należy dodać, iż przechodzenie na nowe technologie jest nieuniknione w sytuacji szybszego wzrostu cen czynników produkcji niż cen róż. Tylko w latach 2003-2012 należało sprzedać 1,6-1,8 razy 
więcej róż by zapłacić za węgiel, siłę roboczą czy nawozy [Wróblewska i Gunerka 2014]. Jak wynika z badań Kubiaka i Marynowskiego [1997], jeszcze w 1997 roku ten sam wskaźnik opłacalności w uprawie tradycyjnej wynosił $140 \%$. W najbliższych latach za przyczyną rosnącego importu róż o niskich cenach z krajów afrykańskich (via aukcja holenderska) [Jabłońska i Leasing 2014] przy rosnących cenach energii elektrycznej tendencje rozwierania się nożyc cen będą się nasilały. Stawia to pod znakiem zapytania prowadzenie uprawy róż w cyklu rocznym z doświetlaniem w polskich warunkach. Już wzrost cen energii odnotowany po 2009 roku (z $0,30 \mathrm{zt} / \mathrm{kW}$ do $0,50 \mathrm{z} / \mathrm{kW}$ ) czynił całoroczną produkcję $\mathrm{w}$ badanym gospodarstwie coraz mniej opłacalną $\mathrm{i}$ był bodźcem do powrotu do wprowadzenia krzewów róż w stan spoczynku w obu szklarniach. Powyższe wskazuje, iż w warunkach globalizacji wdrażanie postępu nie w każdym przypadku jest uzasadnione ekonomicznie.

\section{Wnioski}

1. Produkcję róż pod osłonami cechuje od lat szybki i wielostronny postęp techniczny i technologiczny, wymuszany szybszym wzrostem cen środków produkcji i płac niż cen roślin ozdobnych. Wdrażane są nowe rozwiązania w budownictwie szklarniowym i systemach grzewczych, uprawa w podłożach inertnych $\mathrm{z}$ automatycznym systemem nawożenia i nawadniania sterowanym komputerowo, integrowana ochrona roślin, dokarmianie $\mathrm{CO}_{2} \mathrm{i}$ doświetlanie, pozwalające na całoroczną uprawę. Takie rozwiązania pozwalają istotnie zwiększyć plony i jakość kwiatów, obniżyć nakłady, głównie energii cieplnej, wody i środków chemicznych oraz ograniczyć skażenie środowiska naturalnego.

2. Przestawienie produkcji róż w szklarniach z uprawy ze spoczynkiem zimowym na całoroczną z doświetlaniem, które wraz z nowoczesnymi technologiami upraw miało swój początek w Polsce w połowie lat 90. XX wieku, przynosiło producentom korzyści w postaci wyższej wartości produkcji na jednostkę powierzchni, wyższej nadwyżki bezpośredniej i wyższego dochodu rolniczego brutto. Jednak szybko rosnące koszty energii elektrycznej przy równoczesnym rosnącym imporcie tanich róż z krajów Afryki, czynią całoroczną uprawę w Polsce coraz mniej zasadną ekonomicznie. Miało to wpływ na powrót do wprowadzania krzewów róż w stan zimowego spoczynku w obu szklarniach badanego gospodarstwa. 


\section{Literatura}

DRZEWIECKA A., 2009: Doświetlanie róż pod osłonami, Owoce, Warzywa, Kwiaty 17, s. 73-75.

FRANKOWSKA M., 2011: Znaczenie koncepcji klastrowych tańcuchów dostaw w zwiększeniu międzynarodowej konkurencyjności regionalnych sieci kooperacyjnych, Zeszyty Naukowe Kolegium Gospodarki Światowej 32, s. 102-117. www.yadda.icm.edu.pl/bazhum/element (data dostępu: 13.05.2013).

JABŁOŃSKA L., 1995: Określenie perspektyw polskiego kwiaciarstwa na podstawie dlugookresowej analizy porównawczej jego rozwoju w Polsce i Holandii, Fundacja Rozwój SGGW, Warszawa, s. 57-66.

JABŁOŃSKA L., LEASING K., 2014: Wybrane determinanty zróżnicowania cen róż ciętych na rynku hurtowym $w$ Polsce, Marketing i Rynek 8, s. 469-474.

JABŁOŃSKA L,. OLEWNICKI D., 2011: Zmiany w powierzchni upraw ogrodniczych pod ostonami w Polsce w pierwszej dekadzie XXI w., Zeszyty Naukowe SGGW - Problemy Rolnictwa Światowego 11, z. 4, s. 89-97.

JABŁOŃSKA L., OLEWNICKI D., 2013: Dlugookresowe zmiany w polskim imporcie $i$ eksporcie kwiatów ciętych, Roczniki Ekonomii Rolnictwa i Rozwoju Obszarów Wiejskich t.100 z. 1, 197-210.

KLEIBER T., KLEIBER A.: Uprawa ogórka $w$ podłożach inertnych i organicznych, http:// www.ho.haslo.pl/article.php?id=2610 (data dostępu: 13.05.2013).

KUBIAK K., MARYNOWSKI R., 1997: Produkcja, koszty i opłacalność roślin ozdobnych w Polsce, Centralny Ośrodek Badawczo-Rozwojowy Ogrodnictwa, Warszawa, s. 12-16.

ŁUKOWICZ R., 1993: Systemy oszczędnego nawadniania i nawożenia z nawadnianiem, [w:] Oszczędne technologie w ogrodnictwie szklarniowym, SITO - NOT Oddział w Poznaniu, s. 36-38.

MAJEWSKI E., 1997: Postęp w rolnictwie, [w:] Postęp techniczny a organizacja gospodarstw rolniczych, Wydawnictwo SGGW, Warszawa, s. 19-33.

NOSECKA B., PAWLAK K., POCZTA W., 2011: Wybrane aspekty konkurencyjności rolnictwa. Seria: Konkurencyjność polskiej gospodarki żywnościowej w warunkach globalizacji i integracji europejskiej. IERiGŻ-PIB, s. 8-29.

NOWAK J., 1993: Nawożenie dwutlenkiem węla, [w:] Oszczędne technologie w ogrodnictwie szklarniowym, SITO - NOT Oddział w Poznaniu, s. 43-45.

RUTKOWSKI K., 2008: Analiza energetyczna wybranych typów szklarni, Inżynieria Rolnicza 9(107), s. 249-255.

RUTKOWSKI K., 2011: Najnowsze technologie i rozwiqzania techniczne w produkcji ogrodniczej pod ostonami, www.agengpol.pl (data dostępu: 13.05.2013).

TREDER J., 2000: Róże w szkótce i pod ostonami, [w:] Podtoża do uprawy róż pod osłona$m i$, Instytut Sadownictwa i Kwiaciarstwa w Skierniewicach, s. 15-21.

TREDER J., TREDER W., 2004: Róże w szkótce i pod osłonami, [w:] Nawadnianie róż, Instytut Sadownictwa i kwiaciarstwa w Skierniewicach, 15-22.1991 r.

WRÓBLEWSKA W., GUNERKA L., 2014: Wplyw zmienności cen kwiatów ciętych i środków produkcji na sytuację ekonomicznq producentów kwiatów w Polsce w latach 2003 -2012, Roczniki Naukowe Ekonomii Rolnictwa i Rozwoju Obszarów Wiejskich, t. 101, z. 3, s. 197-204. 


\begin{abstract}
Abstrakt
Celem pracy było przedstawienie nowoczesnych rozwiązań w uprawie róż szklarniowych wdrażanych przez polskich producentów na przykładzie wybranego gospodarstwa oraz ocena efektów ekonomicznych tego postępu. Badania wykazały, że postęp techniczny i technologiczny pozwolił na utrzymanie produkcji róż na opłacalnym poziomie, wyższym w produkcji całorocznej. Jednak stopniowy wzrost importu tanich róż z Afryki i wzrost cen energii elektrycznej czyni doświetlanie krzewów niezasadnym.
\end{abstract}

Słowa kluczowe: róże szklarniowe, innowacje, produktywność, opłacalność

\title{
Progress in greenhouse roses cultivation and its production and economic effects on the example of a chosen farm
}

The aims of the study were to present innovative solutions in the cultivation of greenhouse roses implemented by the Polish producer on the example of a chosen farm and to assess economic effects of this progress. The study has shown that technical and technological progress has made possible to maintain profitability of roses production (higher in year-round production). However, gradual increase in imports of cheap roses from Africa and the increase in electricity prices make shrubs engineering lighting unjustified.

Key words: greenhouse roses, innovations, productivity, profitability 